\title{
The Poet's Gift
}

\author{
by Dr. Michael W. Fox
}

Director, Center for Respect for Life and Environment

The Humane Society of the United States

Poets should be found beneath a wet autumn's mouldering leaf; within the swelling mushroom and the cumulus cloud; above the eagle's matefound cry and in the echo of the swamp edged songs of frogs against the hungry night. But instead they seem to come from books and magazines, arising with no depth when their words do not touch the reader as the poets themselves were touched and transformed by all that they beheld and became.

Then too there are poetic readings and even songs, but such performances (which for sure they are when there is no participation), become mere facsimilies of the soul of poetry until the poet's soul and all are still and empty to receive the poem's seed.

Nature's poem is a glimpse of God's plenum void through the heart's door. Some call Nature's poet, Pan. Many do not know him in the language of the trees and creature life. Nor can they read his stories in the trodden earth, across the winged skies and on the ocean tides.

For all of us God-blind, there is no Pan, until we each receive one poem-seed and grow with it toward the light and then like stars, explode into the night.

Those who have lost their song, have no place within for poem-seeds. They become removed from life as they strive impossibly to conquer death. Their mortal fears destroy Pan's Earth-spun immortality, which once was also theirs.

How sad it is that we must learn this way, by causing so much destruction and inevitable suffering until we find the spark of Pan within our souls that is the Self in everything. This is the Poet's gift.
Come to the emerald glade, Azure domed, suffused with gold Where through the wildwood throbs the song of deep enchantment

From the throats of frog and stream And dappled deer.

As all our ancestors

And the yet unborn

Dream them into being:

And all that we behold and know;

All that we feel and become;

All that we sense and are -

And have been in body, mind and soul.

Come dance in dappled shade

With emerald deer

And play the pipes of Pan.

Following dream-notes into the song

of the wildwombed ones

From whose dimension

All things arise and dance

In loving affirmation.

We all travail,

The lesser and the greater

All have tribulations:

The sun-parched worm,

The drowning moth,

The starving child.

Too late sometimes

The benevolent heart

Yet what else can brighten

Those eyes of love-lost,

Or soften those of pain and anger?

Those who will rescue

Worms and moths and live

So other's children do not starve. 